\title{
Invasive mikania in Chitwan National Park, Nepal: the threat to the greater one-horned rhinoceros Rhinoceros unicornis and factors driving the invasion
}

\author{
Sean T. Murphy, Naresh Subedi, Shant Raj Jnawali, Babu Ram Lamichiane \\ Gopal Prasad Upadhyay, Richard Kock and Rajan Amin
}

\begin{abstract}
As part of a census of the Indian rhinoceros Rhinoceros unicornis a survey was conducted to measure the extent of invasion by the neotropical plant mikania Mikania micrantha across major habitats of Chitwan National Park important for the conservation of the rhinoceros. Previous work has demonstrated that this fire-adapted plant can smother and kill native flora such as grasses and sapling trees, several of which are important fodder plants of the rhinoceros. Here, additional studies were conducted on the risks of anthropogenic factors (natural resource collection and grassland burning) contributing to the spread and growth of the plant. Mikania is currently found across $44 \%$ of habitats sampled and almost $15 \%$ of these have a high infestation $(>50 \%$ coverage). Highest densities were recorded from riverine forest, tall grass and wetland habitats and this is where the highest numbers of rhinoceroses were recorded in the habitats surveyed during the census. Local community dependence on natural resources in the core area of the Park is high. The range and volume of resources (e.g. fodder) collected and the distances travelled all pose a high risk of the spread of mikania. Of greater significance is the annual burning of the grasslands in the Park by local communities, estimated at $25-50 \%$ of the total area. It is imperative, therefore, that core elements of a management plan for mikania incorporate actions to control burning, reduce spread and raise awareness about best practice for local resource management by local communities.
\end{abstract}

Keywords Chitwan National Park, human-mediated spread, Indian rhinoceros, invasive plant management, invasive species, mikania distribution, Nepal

\footnotetext{
SEAN T. MURPHY (Corresponding author) CABI Europe-UK, Bakeham Lane Egham, Surrey TW20 9TY, UK. E-mail s.murphy@cabi.org

NARESH Subedi and Babu Ram LamichHane National Trust for Nature Conservation, Biodiversity Conservation Centre, Chitwan, Nepal

Shant Raj Jnawali National Trust for Nature Conservation, Khumaltar, Lalitpur, Nepal

Gopal Prasad Upadhyay Department of National Parks and Wildlife Conservation, Kathmandu, Nepal

RICHARD KocK* and RAJAN AmIn Zoological Society of London, Regents Park London, UK

${ }^{\star}$ Current address: Royal Veterinary College, North Mymms, Hertfordshire, UK

Received 17 March 2012. Revision requested 20 June 2012.

Accepted 14 August 2012.
}

\section{Introduction}

$\mathrm{M}$ ikania Mikania micrantha is a fast-growing perennial climber, capable of producing large amounts of biomass, and is highly invasive in humid tropical and subtropical regions of Asia and the Pacific (Waterhouse, 1994). It is commonly called mile-a-minute weed because of its exceptionally fast growth rate (Holm et al., 1977). It is a major threat to agriculture and biodiversity as it is reported to smother and retard or kill a wide variety of young trees, crops, native plants and fodder grasses (Palit, 1981; Muniappan \& Viraktamath, 1993; Muraleedharan \& Anitha, 2000). A native to tropical and subtropical Central and South America, mikania usually only occurs in low abundance in these regions (Barreto \& Evans, 1995).

Mikania was first reported in the east of Nepal in the early 1960 (Tiwari et al., 2005) and appears to be spreading aggressively westwards along the terai (grassland-forest) habitat zone in the south of Nepal (Poudel et al., 2005) where it has become a major threat to protected areas. Anecdotal evidence suggests it may have spread from Assam, India, to east Nepal through the transport of tea seedlings (Tiwari et al., 2005). It probably reached Chitwan National Park in the early 1990 s as it was identified there in 1997 at a low density and seems not to have been seen by forest guides a few years prior to this (H. Evans, pers. comm.). It is now the principal invasive plant in the Park and is widespread and abundant particularly in areas closer to the main rivers, the Rapti flowing east to west and the Narayani flowing into the Rapti from the north-east. Qualitative observations by the National Trust for Nature Conservation in recent years suggest that the Indian rhinoceros Rhinoceros unicornis, also known as the greater one-horned rhinoceros, and other large herbivore populations have declined in areas with high mikania infestation. Thus mikania is a major concern as it has the potential to destroy prime habitats of threatened and important species in Chitwan National Park, a UNESCO World Heritage Site.

Mikania is a fast-growing climber with a high reproductive rate (sexual and asexual) and is also fire-adapted. Asexual reproduction is from roots that develop from nodes on small sections of the stem. Whereas these natural biological characteristics give the plant the potential to spread, anthropogenic factors can either cause or greatly exacerbate the actual spread and growth of mikania; this is 
in common with some other invasive plant species in the Indian subcontinent (Murphy, 2001). In particular, studies have shown that burning of vegetation and manual weed control for crops, common practices in the lowland grasslands of Nepal and India, can promote spread. For example, in shifting agriculture in north-east India, after slash and burn in forests, mikania vigour was greater than in unburnt plots, indicating that mikania can survive after fire (Swamy \& Ramakrishnan, 1987a, 1988). In addition, it has been shown that mikania is more efficient than most native plants at utilizing important nutrients when these and light are not limiting (Swamy \& Ramakrishnan, 1987b), and after burning nutrients are often plentiful. Moreover, efforts at manual cutting and removal can often promote local dispersal from regeneration of small plant sections that are dropped, as has been reported from south China (Wang et al., 2003) and India (Kerala Forest Research Institute, pers. comm.).

In view of the threat of mikania to species of conservation concern in Chitwan National Park a draft management plan for the plant is under development by the Department of National Parks and Wildlife Conservation and National Trust for Nature Conservation, with support from CAB International and the Zoological Society of London. Herbicides cannot be used in the core of the Park because of the risk of side effects (DNPWC, 2009) and thus a different approach is needed. As a basis for a management plan, studies on mikania ecology and dispersal have been conducted to identify factors that could be driving or exacerbating the invasion, and a special emphasis has been placed on anthropogenic factors, as the core area of the Park is used by local people for resource extraction. This information will be used to prioritize areas for immediate control of mikania and to design an initial framework of interventions based on cultural and mechanical controls that involve local communities. Such studies will be of direct relevance to other affected protected areas. Here we report on the current extent of the mikania invasion in Chitwan National Park, particularly in vegetation zones important for the Indian rhinoceros, and on the activities of communities in the buffer zone that may exacerbate mikania infestations.

\section{Study area}

Chitwan National Park (Fig. 1) was established in 1973 as the first national park in Nepal and is situated in a valley bounded by the Siwalik Hills in the terai region (Sapkota, 2007). The Park includes a core conservation area of $932 \mathrm{~km}^{2}$ and an additional $750 \mathrm{~km}^{2}$, surrounding the core area, set up as a buffer zone. Climate is subtropical monsoonal, with a mean annual rainfall of $2,100 \mathrm{~mm}$. The Park supports a wide variety of plants, fish, reptiles, birds and mammals. The habitats can be broadly classed into: Sal Shorea robusta forest, riverine/subtropical mixed hardwood forests

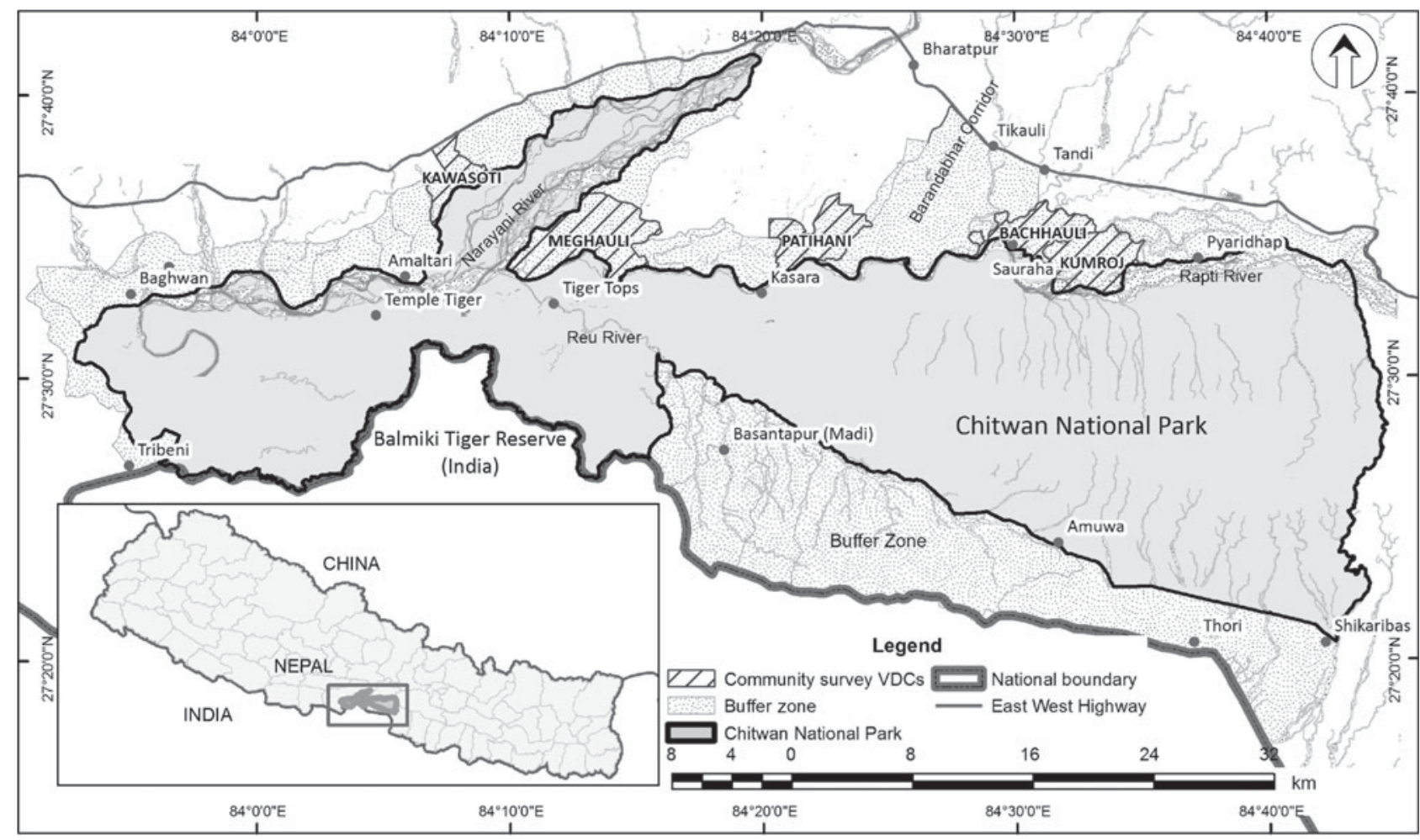

FIG. 1 Chitwan National Park, main rivers and surrounding buffer zones, and the locations of the sample of five Village Development Communities (VDCs; Table 1). The rectangle on the inset indicates the location of the main map in southern Nepal. 
(e.g. Trewia nudiflora, Bombax ceiba and Dalbergia sissoo), tall grasslands (e.g. Saccharum spontaneum, Narenga porphyracorma, Phragmites karka), short grasslands (e.g. Imperata cylindrica), wetlands (including lakes) and shrublands (Laurie, 1982; Dinerstein \& Price, 1991; DNPWC, 2009). The riverine/subtropical mixed hardwood forests and grassland habitats tend to form a mosaic in the moister areas of the Park.

The buffer zone was delineated in 1996 with the aim of creating local ownership and involving communities in conservation. The buffer zone communities receive part of the total income of the Park for local development and conservation (DNPWC, 2006a). The buffer zone includes 37 Village Development Communities of Chitwan and Nawalparasi districts around the Park, with $>250,000$ inhabitants. Ethnically, the communities consist mostly of hill migrants and indigenous people, the latter include Tharu, Bote and Musahar. The buffer zone communities are allowed to enter the core area of the Park for a few weeks early in the year to collect resources such as fodder grasses. They also burn parts of the core area to encourage the regeneration of grasses.

\section{Methods}

A national rhinoceros census conducted in May 2008 (DNPWC, 2009) provided an opportunity to obtain information on the level of invasion of mikania while saving time and resources. In summary, the rhinoceros census in Chitwan National Park was conducted by dividing all potential rhinoceros habitats into 16 contiguous blocks situated east to west in the northern and central part of the Park, as the habitat in the south is generally too dry and hilly for rhinoceroses. These blocks were surveyed by observers on elephants. There was one observer per elephant and the elephants moved in parallel through the blocks along transects, the block size determining the number of elephants used. The distance between two elephants was maintained at c. 100-200 $\mathrm{m}$ in open grasslands and $50 \mathrm{~m}$ in dense forests, to ensure areas were thoroughly covered. The census covered most of the core area of the Park, buffer zone community forests and the Barandabar Forest corridor (in the north-eastern boundary of the Park) as this is also an important conservation area.

The method for measuring mikania infestation involved the assessment of mikania cover by each observer within an approximately semi-circular plot of $50 \mathrm{~m}$ in front, left and right of the elephant (except in dense forest where every other observer made the observations). The level of infestation was measured using a simple ranking of cover within the area as: 0 , absence; $1 \leqslant 50 \% ; 2>50 \%$. Assessments were made every c. 30 minutes during the census and thus sampling was approximately proportional to the area covered by each habitat.
The type of habitat and position of each plot were recorded using a geographical positioning system. The habitats that rhinoceroses are usually found in were divided into five types: riverine/subtropical mixed hardwood forests, Sal forest, tall grassland, short grassland, and wetland (DNPWC, 2009). Over 40 observers were trained to assess the level of mikania invasion and record the habitats in which the plant occurred. The information on the recorded sheets was checked and entered into a spreadsheet at the end of each survey day. The level of invasion of mikania was summarized as frequencies of plots invaded in each habitat. Rhinoceros count data was similarly summarized in relation to habitats assessed. The mikania data was mapped using ArcGIS v. 9.3 and 10 (ESRI, Redlands, USA).

A broad assessment of the possible role of anthropogenic factors in the spread of the plant was made during a general survey of buffer zone communities adjoining the northern part of Park, who use the Park for resource collection (NTNC, 2009). Rai et al. (2012) describe methods used for the general survey but specific methods relevant to the assessment reported here, conducted on the same communities, are as follows. Two main groups of questions were posed: (1) what resources are collected by communities that could serve as vectors for invasive plant material from the core area of the Park and how far do people travel into this area, and (2) do communities burn vegetation in the core area of the Park and if so, why, by how much, and when?

Five Village Development Communities were selected for the community survey. Selection was based on two main criteria: being adjacent to the Park and having a high proportion of indigenous/ethnic people (e.g. Tharu, Bote, Darai). The last point is based on the assumption that ethnic communities are more dependent on natural resources for their livelihood compared to other communities. Using these criteria, the Village Development Communities of Kumroj, Bachhauli, Patihani and Meghauli from Chitwan district and Kawasoti from Nawalparasi district were selected for the survey (Fig. 1). The ethnic composition of each is shown in Table 1. From each Communitiy two to three wards adjacent to the Park were selected. A total of 2,683 households were surveyed across the five Communities (Table 1).

Information about the questions was collected using a structured questionnaire. From each Village Development Community c. 30 respondents (one respondent per household) were interviewed. Households were selected from numbered voting lists of the wards; a household was selected randomly from each ward and then every 1oth household selected after this.

The survey was conducted from April to May 2009 and the questionnaires were completed through direct interviews with the respondents. Two researchers were involved in the questionnaire survey, one interviewer and one 
TABLE 1 Ethnic composition of the sample of five Village Development Communities (Fig. 1) and the wards surveyed in each Community.

\begin{tabular}{|c|c|c|c|c|c|c|c|}
\hline \multirow[b]{2}{*}{ Community } & \multirow[b]{2}{*}{$\begin{array}{l}\text { Total no. of } \\
\text { households }\end{array}$} & \multicolumn{4}{|c|}{ Population structure (\% of households) } & \multicolumn{2}{|c|}{ Wards \& households surveyed } \\
\hline & & Brahmin/Chhetri & $\begin{array}{l}\text { Newar/Gurung/ } \\
\text { Magar/Tamang }\end{array}$ & Tharu & Other & Ward no. & $\begin{array}{l}\text { Total no. } \\
\text { households }\end{array}$ \\
\hline Kumroj & 1,348 & 46.7 & 8.0 & 33.6 & 11.6 & $1 \& 2$ & 314 \\
\hline Bachhauli & 1,127 & 30.0 & 12.1 & 52.1 & 5.5 & $1,2 \& 7$ & 464 \\
\hline Patihani & 1,701 & 54.6 & 10.1 & 12.6 & 22.6 & $1,6 \& 8$ & 782 \\
\hline Meghauli & 1,854 & 41.1 & 11.7 & 16.1 & 30.4 & $5 \& 9$ & 757 \\
\hline Kawasoti & 2,080 & 48.5 & 11.8 & 32.2 & 7.4 & $7,8 \& 9$ & 366 \\
\hline
\end{tabular}

TABLE 2 Percentage invasion of main Indian rhinoceros Rhinoceros unicornis habitat types by mikania Mikania micrantha in Chitwan National Park (Fig. 1), based on assessed plots.

\begin{tabular}{|c|c|c|c|c|c|}
\hline \multirow[b]{2}{*}{ Habitat types } & \multirow{2}{*}{$\begin{array}{l}\text { Total no. of } \\
\text { assessed plots }\end{array}$} & \multicolumn{3}{|c|}{ Mikania cover (\% total plots invaded) } & \multirow{2}{*}{$\begin{array}{l}\text { Total } \% \text { of } \\
\text { plots invaded }\end{array}$} \\
\hline & & 0 & $\leqslant 50$ & $>50$ & \\
\hline $\begin{array}{l}\text { Riverine/subtropical mixed } \\
\text { hardwood forest }\end{array}$ & 739 & 36.9 & 38.8 & 24.2 & 63.0 \\
\hline Wetland & 24 & 58.3 & 33.3 & 8.3 & 41.6 \\
\hline Tall grassland & 324 & 62.0 & 28.1 & 9.9 & 38.0 \\
\hline Short grassland & 134 & 64.9 & 29.9 & 5.2 & 35.1 \\
\hline Sal forest & 344 & 87.6 & 10.3 & 2.0 & 12.3 \\
\hline Total/total \% of plots & 1,565 & 55.9 & 29.5 & 14.5 & 44.0 \\
\hline
\end{tabular}

recorder. Summaries of respondents' answers were generated with SPSS v. 11.5 (SPSS Inc., Chicago, USA).

\section{Results}

\section{Assessment of mikania distribution and abundance}

The assessment of mikania distribution and level of invasion was undertaken in a total of 1,565 locations. The area surveyed was $470 \mathrm{~km}^{2}$ and took 3,107 elephant hours to complete. As the assessments were taken uniformly across the habitats, the total number of assessed plots in each habitat provides a relative measure of the geographical size of the habitats (Table 2). Overall, $44 \%$ of plots contained mikania and a high invasion rate $(>50 \%)$ was recorded in c. $15 \%$ of the plots (Table 2). The distribution of levels of invasion of mikania across Chitwan National Park is shown in Fig 2.

Riverine/subtropical mixed hardwood forests were found to be most invaded by mikania $(63.1 \%$ of plots invaded, $24.2 \%$ of the plots highly invaded). Habitat types in descending order of magnitude of invasion were wetland, tall grassland, short grassland and Sal forest (Table 2).

The locations of 381 rhinoceroses recorded across the five habitats are shown in Table 3. In terms of numbers of individuals, $87 \%$ of the rhinoceroses recorded were sighted in tall grasslands, riverine/subtropical mixed hardwood forests and wetlands. These habitats also have some of the highest levels of mikania invasion $(38,63$ and $42 \%$ of the plots in these habitats; Table 2). Rhinoceros densities in relation to the various habitat types were also examined, using an index estimated from the number of assessed plots per habitat (Table 2), as each habitat type occupied a different percentage of the sampling area. This analysis (last column, Table 3) indicates the importance of wetlands for the rhinoceroses and these habitats are the second-most highly invaded by mikania.

\section{Human activities and mikania spread}

A total of 156 respondents, 53\% male and $47 \%$ female, were interviewed, which represented c. $6 \%$ of the total number of households in the wards surveyed (Table 1 ). The highest numbers of respondents were from Tharu, Bote and Musahar communities (45\%) followed by Brahmin and Chhetri communities (32\%), Magar, Gurung and Tamang communities (17\%), Newar and other communities (6\%). The primary occupation of $>85 \%$ of the respondents was farming. The survey included community leaders and elderly people and it was found that they generally had the most in-depth knowledge about the questions being asked.

The survey results showed that people living in the buffer zone depend on the core area of the Park for resources such as fuelwood, fodder, thatching materials, vegetables, fish and grazing. The level of dependency on each of these resources varies across the Village Development 


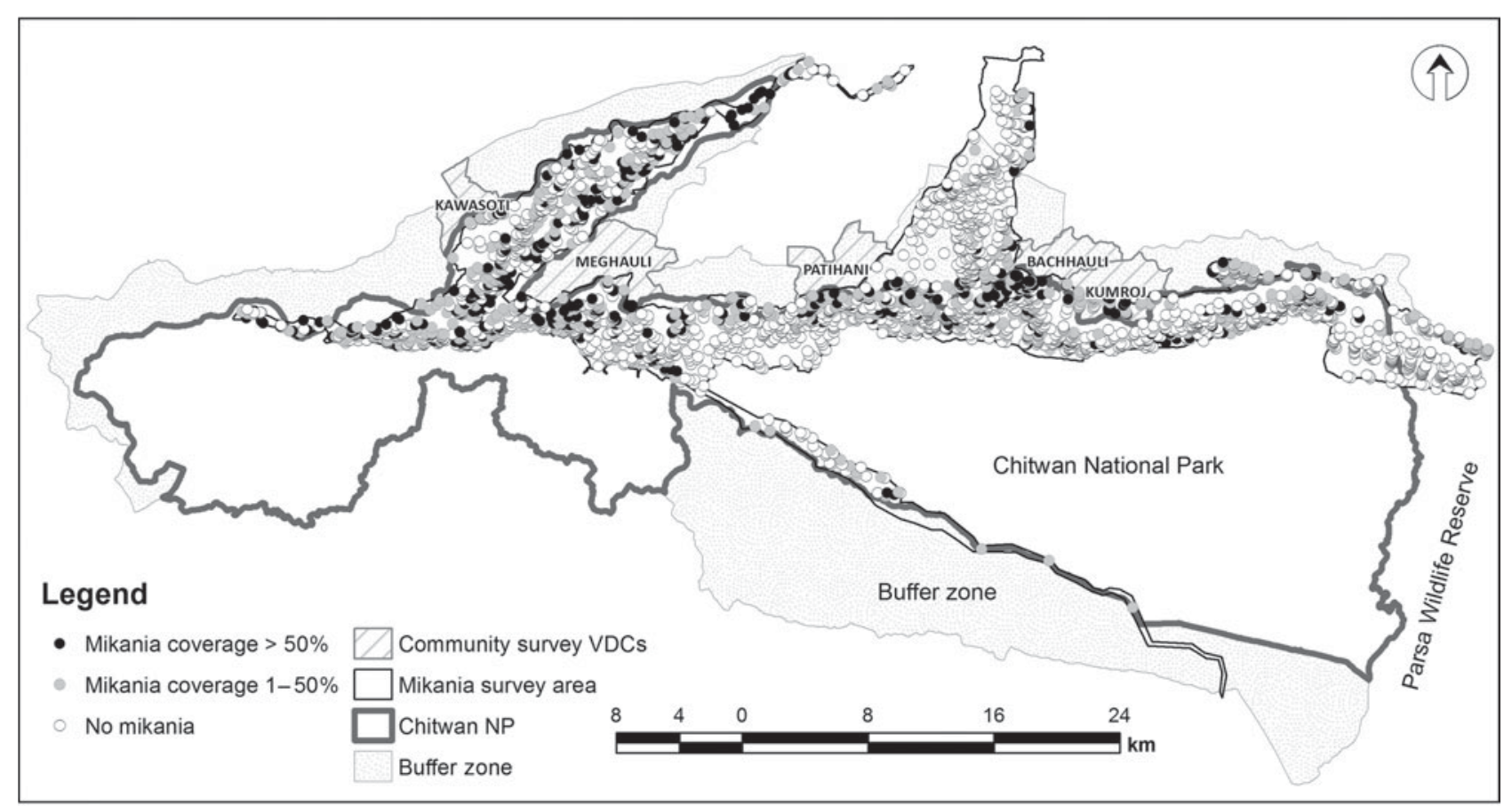

FIG. 2 The distribution of infestation levels of mikania Mikania micrantha in Chitwan National Park (NP) and surrounding buffer zones, and the locations of the sample of five Village Development Communities (VDCs; Table 1).

TABle 3 Distribution of rhinoceroses by habitat type in Chitwan National Park, as recorded in the May 2008 national rhinoceros census. The last column gives an index of rhinoceros density per habitat estimated from the number of assessed plots per habitat (Table 2).

\begin{tabular}{lll}
\hline Habitat type & $\begin{array}{l}\text { Total no. of } \\
\text { rhinoceroses }(\%)\end{array}$ & $\begin{array}{l}\text { No. of rhinoceroses } \\
\text { per assessed plot }\end{array}$ \\
\hline $\begin{array}{l}\text { Tall grassland } \\
\text { Riverine/subtropical } \\
\text { mixed hardwood }\end{array}$ & $160(42.0)$ & 0.49 \\
$\quad$ forest & & 0.19 \\
Wetland & $34(8.9)$ & \\
Short grassland & $30(7.9)$ & 1.42 \\
Sal forest & $18(4.7)$ & 0.22 \\
Total & $381(100)$ & 0.05 \\
\hline
\end{tabular}

Communities and settlements but in most cases dependency on the core area of the Park was high compared with sources from community and private forests. An example is fodder (which is highly infested with mikania) collection, which all Communities (except Kawasoti) were highly dependent on in the core area (Fig. 3). The mean amount (kg) of grass removed from the core area per household per annum by the Village Development Communities (except Kawasoti) is shown in Fig. 4. From the interviews it was clear that in general local people do not remove mikania from collected fodder grass before transport.

The movement of local people inside the core area of the Park varied with season and the availability of targeted

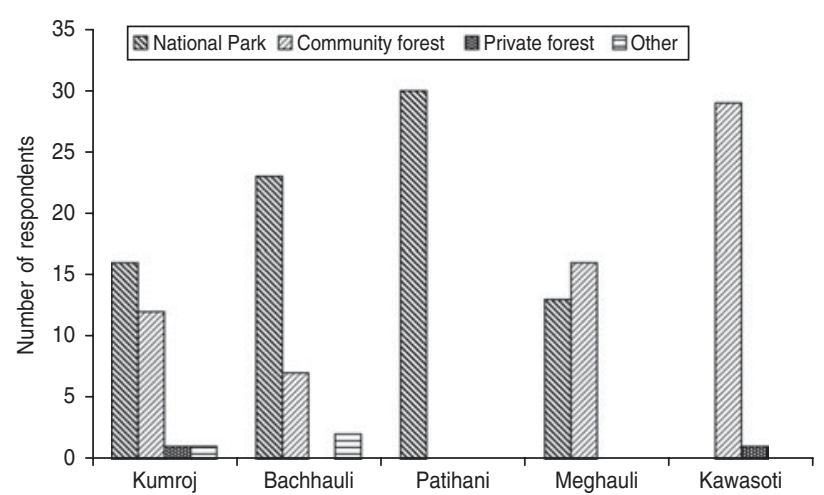

FIg. 3 The number of respondents in each Village Development Community who collect fodder from the core area of Chitwan National Park (Fig. 1) compared to those who collect fodder from other areas (NTNC, 2009).

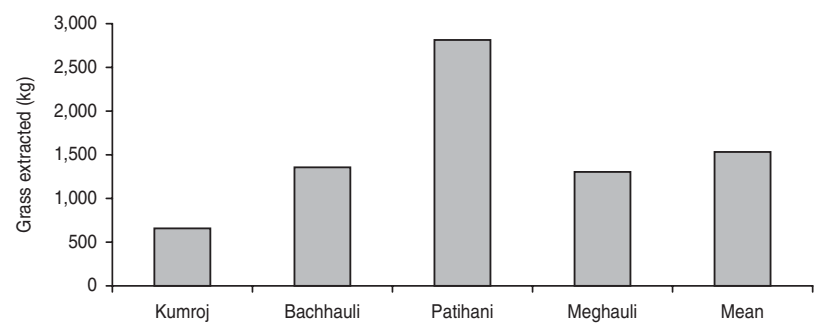

Fig. 4 The mean amount of grass (fodder) extracted per household per year from the core area of Chitwan National Park (Fig. 1) by four of the Communities (Fig. 3) (NTNC, 2009). 


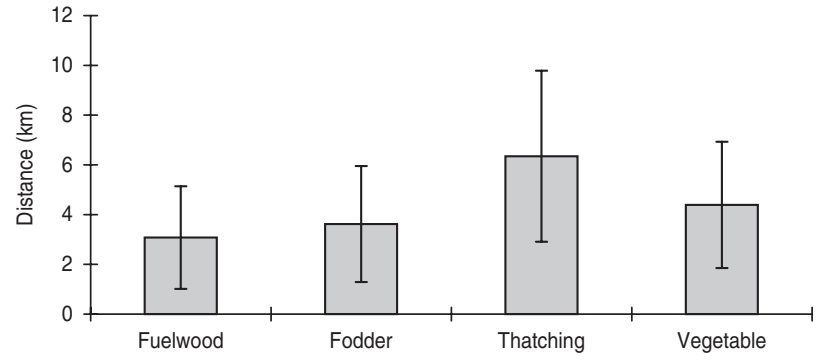

FIG. 5 Mean \pm SD distance $(\mathrm{km})$ travelled by people to collect fuelwood, fodder, thatching and wild vegetable resources in the core area of Chitwan National Park (Fig. 1) (NTNC, 2009).

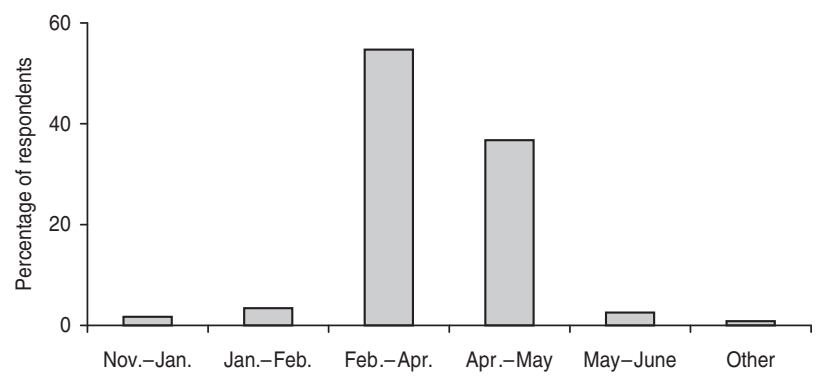

FIG. 6 Burning activity in the core area of Chitwan National Park (Fig. 1) by month, based on respondents' views (NTNC, 2009).

resources but it was clear that the period during which people entered the core area was much greater than that permitted by the authorities. Some of the distances travelled by local people can be large; e.g. the people of Bachhauli Village Development Community travel an average of $8.4 \mathrm{~km}$ and people of Patihani travel an average $5.9 \mathrm{~km}$ for thatch grasses. In general, people across the Village Development Communities (not including Kawasoti) travel the furthest for thatch grasses and shortest distance for fuelwood (Fig. 5).

Burning is a traditional practice in the core area of the Park. The reasons given by the respondents for burning grasslands were, in descending order, to expose cane for collection, generate new grass shoots for elephants and for thatch, honey gathering, and accidental burning. Approximately $55 \%$ of respondents claimed that burning generally takes place during February-April but c. $35 \%$ claimed April-May (Fig. 6). In practice most of the areas are burnt during March-April (NTNC, 2009). The late fires during the last part of April and May are hazardous because of the hot and dry conditions.

In four of the five Village Development Communities most respondents reported that $25-50 \%$ of the core area is burnt (Fig.7); in the Bachhauli Village Development Community most respondents reported that $50-75 \%$ of the core area is burnt. The extent of burning largely depends

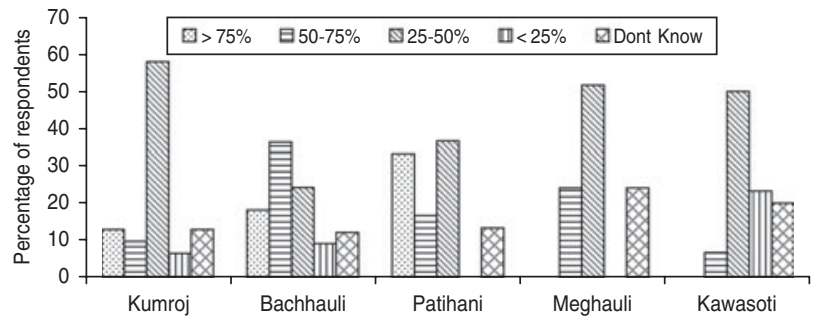

FIg. 7 Extent of the core area of Chitwan National Park (Fig. 1) burnt annually, as perceived by people of the five Village Development Communities (NTNC, 2009).

on the season, the amount of pre-monsoon rainfall and the efforts of Park authorities to control the fire. During the dry season (March-May) of $2009>75 \%$ of the Park was burnt severely as it was one of the driest years of the decade (NTNC, 2009). Only wetlands and moist riverine/subtropical hardwood forests remained unburnt, because of their high moisture.

All of the respondents agreed that burning in and around the Park has been taking place for $>20$ years. Forty-five percent of the respondents reported that burning has either decreased or not changed compared to the past but only $11 \%$ of the respondents claimed that burning has increased.

\section{Discussion}

Chitwan National Park contains habitats vitally important for the conservation of the Indian rhinoceros and many other species characteristic of the terai region. Of crucial importance is the unique grass-tree-wetland mosaic on which the rhinoceros depends. An earlier study by Sapkota (2007) has demonstrated the negative impact that mikania has on plant species. For example, in highly-invaded grassland many I. cylindrica and S. spontaneum plants were found dead and no new culms were observed sprouting from the rootstocks, and in highly invaded riverine/subtropical hardwood forests saplings of B. ceiba, D. sissoo and Acacia catech $u$ had died and no regeneration was observed.

Although rhinoceroses forage and roam across a number of habitat types in the Park (Laurie, 1982) they are most frequently found in the mosaics of tall grassland and riverine/subtropical mixed hardwood forest (Laurie, 1982; Dinerstein \& Price, 1991). Similar observations have been made in Bardia National Park (Steinheim et al., 2005). A key component of the tall grasslands are Saccharum spp., especially S. spontaneum, and these form a major part of the rhinoceros' diet (Laurie, 1982; Steinheim et al., 2005) but rhinoceroses also browse shrubs and the leaves, twigs and fruits of trees and saplings.

Forty-four percent of the rhinoceros habitats in Chitwan National Park are now affected by mikania. The riverine/subtropical mixed hardwood forests, tall 
grass and wetland habitats are the most highly invaded and this is where the highest number (87\%; Table 3) of rhinoceroses were recorded. No quantitative estimates could be made of the extent to which mikania may already be affecting rhinoceros numbers in these habitats but anecdotal evidence does exist on the impact of mikania on the rhinoceros populations. Data from regular monitoring in the Baghmara and Chitrasen buffer zone community forests suggest a negative impact. In these areas $>30$ rhinos used to be seen regularly in the late 1990 s but now $<_{15}$ rhinoceroses are known to utilize them. The decline does not appear to be because of poaching as there have been extensive surveys in the area and only a few carcasses have been detected (NTNC, unpubl. data).

Rai et al. (2012) report that in all the buffer zone communities studied people seemed to be aware of and recognize mikania; there was also a broad consensus that mikania is likely to be having a severe negative effect on natural resources. Overall, the communities reported that mikania is spreading rapidly. It was also clear that mikania is not utilized in any significant way apart from supplementing fodder grasses for goats during the dry period. Twentythree percent of the households sampled indicated that mikania is collected for fodder on an ad hoc basis from the core Park and community forests (NTNC, 2009; Rai et al., 2012).

In our socio-economic study all the Village Development Communities (apart from Kawasoti) had a high dependency on the Park for livestock fodder, thatching material, fuelwood, vegetables and grazing. Livestock are an integral part of traditional subsistence farming and most of the households own livestock. Mikania is common across much of the grassland areas and is not necessarily removed from the grass cut for fodder.

People enter the core area of the Park to collect resources during a significant period of the year, whereas the permitted entry period is only a few weeks in the early part of the year (NTNC, pers. comm.). The distances travelled by people for resources varied between the Village Development Communities and the resource being collected but mean distance for each resource is at least $4 \mathrm{~km}$. It is known that mikania can be spread accidentally during cutting (Wang et al., 2003) and thus the risk of inadvertent spread throughout the Park in the course of community activities is high.

Of more significance as a factor generating the growth and spread of mikania is probably the burning of vegetation by those who live and work in and around the Park. The majority of people interviewed reported that $25-50 \%$ of the core area of the Park is burnt annually. Burning is uncontrolled and new mikania growth on burnt patches is frequently seen after the main monsoon, probably having sprouted from unburnt root systems but also from windblown seed. This new growth will have an advantage over native plant species because of the plentiful nutrient supply and good sunlight.

Our survey confirms that mikania is established in a wide area in the core of the Park, in places totally smothering native vegetation, and thus the potential for mikania to destroy prime habitat for rhinoceroses is high. This study also indicates that human activity is exacerbating mikania spread and growth through collection and transport of the plant and through the annual burning of the Park. These factors have important and direct implications for a management plan for controlling mikania in the core of the Park. There is a clear need to increase awareness among communities and policy makers about the impacts of mikania on natural resources and the risk of inadvertent spread of the plant if cut material is moved around. But the main issue that needs to be addressed is the extensive and uncontrolled burning that takes place each year. Ideally, the burning needs to be controlled such that native vegetation in the Park has a chance to survive and out-compete mikania, which is fire-adapted. One option would be to restrict burning of some areas important for the rhinoceros to once every few years; some controlled burning is important to maintain the grassland habitats in the longer term but further research is needed to determine the optimal regime for burning. Protection of areas from burning can be achieved by the use of fire breaks but the local communities and others who set fires need to be engaged in the plan, to avoid accidental burning of these areas. The spread of mikania westwards also needs to be monitored; this can be done by the establishment of permanent sampling plots throughout the Park. It will be important to include the general management measures recommended here in relevant conservation action plans, such as that for the rhinoceros (DNPWC, 2006b).

Furthermore, a greater understanding of the impacts and dynamics of mikania in relation to major habitats is required. The extent of invasion in different plant communities appears to vary, with some grassland types badly affected. This information is necessary to justify longerterm intervention options such as biological control, as this is the most viable and sustained solution and will complement shorter-term measures. The most promising biological control agents are three rust species from the neotropical native range of the weed (Ellison, 2001), which kill the leaf and the stem, affecting the whole plant. The highly selective rust fungus Puccinia spegazzinii, which can only survive on mikania, is being introduced into India and China and lessons drawn from these countries will be invaluable (Ellison \& Murphy, 2001; Sankaran et al., 2001). The threat of invasive alien species to biodiversity is a problem that may undermine other conservation efforts. Actions must be put in place to address this issue but these must be based on a sound understanding of the biology of invasions. 


\section{Acknowledgements}

The authors would like to thank the UK government's Darwin Initiative and WWF, Nepal. Retired DNPWC Director General Mr Bajimaya and all the census participants are sincerely thanked for their continued commitment to conservation of the Indian rhinoceros.

\section{References}

Barreto, R.W. \& Evans, H.C. (1995) The mycobiota of the weed Mikania micrantha in southern Brazil with particular reference to fungal pathogens for biological control. Mycological Research, 99, 343-352.

Dinerstein, E. \& Price, L. (1991) Demography and habitat use by greater one-horned rhinoceros in Nepal. Journal of Wildlife Management, 55, 410-411.

DNPWC (Department of National Parks and Wildlife Conservation) (2006a) Chitwan National Park and Buffer Zone Management Plan 2006-2011. DNPWC, Ministry of Forests and Soil Conservation, Government of Nepal, Kathmandu, Nepal.

DNPWC (Department of National Parks and Wildlife Conservation) (2006b) The Greater One-horned Rhinoceros Conservation Action Plan for Nepal (2006-2011). DNPWC, Ministry of Forests and Soil Conservation, Government of Nepal, Kathmandu, Nepal.

DNPWC (Department of National Parks and Wildlife Conservation) (2009) The Status and Distribution of the Greater One-horned Rhinoceros in Nepal. DNPWC, Ministry of Forests and Soil Conservation, Government of Nepal, Kathmandu, Nepal.

ElLison, C.A. (2001) Classical biological control of Mikania micrantha. In Alien Weeds in Moist Tropical Zones, Banes and Benefits (eds K.V. Sankaran, S.T. Murphy \& H.C. Evans), pp. 131-138. Kerala Forestry Research Institute, India \& CABI Bioscience, Ascot, UK.

Ellison, C.A. \& Murphy, S.T. (2001) Puccinia spegazzinii de Toni (Basidiomycetes Uredinales) a Potential Biological Control Agent for Mikania micrantha Kunth. Ex H.B.K. (Asteraceae) in India. Unpublished Report. CABI Bioscience, Ascot, UK.

Holm, L.G., Plucknett, D.L., Pancho, J.V. \& Herberger, J.P. (1977) The World's Worst Weeds-Distribution and Biology. University Press of Hawaii, Honolulu, USA.

LAURiE, A. (1982). Behavioural ecology of the greater one-horned rhinoceros (Rhinoceros unicornis). Journal of Zoology, 196, 307-341.

Muniappan, R. \& Viraktamath, C.A. (1993) Invasive alien weeds in the Western Ghats. Current Science, 64, 555-557.

Muraleedharan, P.K. \& Anitha, V. (2000) The economic impact of mikania on teak plantations in Kerala. Indian Journal of Forestry, 23, 248-251.

Murphy, S.T. (2001) Alien weeds in moist tropical zones of India: population characteristics, ecology and implications for impact and management. In Alien Weeds in Moist Tropical Zones, Banes and Benefits (eds K.V. Sankaran, S.T. Murphy \& H.C. Evans), pp. 20-27. Kerala Forestry Research Institute, India \& CABI Bioscience, Ascot, $\mathrm{UK}$.

NTNC (National Trust for Nature Conservation) (2009) Community Survey on Human-mediated Factors Driving the Spread of Invasive Alien Plant Species in Chitwan National Park. Unpublished Report. NTNC, Kathmandu, Nepal.
PALIT, S. (1981) Mikania: a growing menace in plantation forestry in West Bengal. Indian Forester, 107, 96-101.

Poudel, A., Baral, H.S., Ellison, C., Subedi, K., Thomas, S. \& Murphy, S.T. (2005) Mikania micrantha Weed Invasion in Nepal: A Summary Report of the First National Workshop for Stakeholders, Nepal. Unpublished Report. Himalayan Nature, IUCN-Nepal, \& CAB International, Wallingford, UK.

Rai, R.K., Scarborough, H., Subedi, N. \& Lamichiane, B. (2012) Invasive plants - do they devastate or diversify rural livelihoods? Rural farmers' perception of three invasive plants in Nepal. Journal for Nature Conservation, 20, 170-176.

Sankaran, K.V., Muraleedharan, P.K. \& Anitha, V. (2001) Integrated Management of the Alien Invasive Weed Mikania micrantha in the Western Ghats. Kerala Forestry Research Institute, Peechi, India.

SA кота, L. (2007) Ecology and management issues of Mikania micrantha Chitwan National Park, Nepal. Banko Janakari, 17, 27-39.

Steinheim, G., Wegge, P., Fjellstad, J.I., Jnawali, S.R. \& Weladji, R.B. (2005) Dry season diets and habitat use of sympatric Asian elephants (Elephas maximus) and greater one-horned rhinoceros (Rhinoceros unicornis) in Nepal. Journal of Zoology, 265, $377-385$.

SWAmy, P.S. \& Ramakrishnan, P.S. (1987a) Effect of fire on population dynamics of Mikania micrantha H.B.K. during early succession after slash and burn agriculture (jhum) in northeastern India. Weed Research, 27, 397-404.

Swamy, P.S. \& RAmakrishnan, P.S. (1987b) Contribution of the weed Mikania micrantha during secondary succession following slash and burn agriculture in northeastern India II: nutrient cycling. Forest Ecology and Management, 22, 239-249.

SWAMY, P.S. \& RAMAKRISHNAN, P.S. (1988) Effect of fire on growth and allocation strategies of Mikania micrantha under early successional environments. Journal of Applied Ecology, 25, 635-658.

Tiwari, S., Adhikari, B., Siwakoti, M. \& Subedi, K. (2005) An Inventory and Assessment of Invasive Alien Plant Species of Nepal. IUCN, Kathmandu, Nepal.

WANG, B., Li, M., Zhang, J., ZAN, Q., Zhang, W. \& LiaO, W. (2003) Invasion, ecology and management of Mikania micrantha in South China. In Proceedings of the International Symposium on Exotic Pests and their Control (eds R. Zhang, C. Zhou, P. Pang, W. Zhang, D. Gu \& Yi Pang), pp. 155-165. Zhongshan (Sun Yat Sen) University Press, Guangzhou, China.

Waterhouse, D.F. (1994) Biological Control of Weeds: Southeast Asian Prospects. Australian Centre for International Agricultural Research, Canberra, Australia.

\section{Biographical sketches}

SEAN T. MURPhy studies the biology of populations, factors generating outbreaks, and the development of prevention and management methods. Naresh Subedi runs biodiversity research and monitoring projects in Nepal. SHANT RAJ JNAWALI specializes in rhinoceros, tiger and elephant population management in humandominated landscapes in Nepal. Babu Ram Lamichiane is interested in habitat dynamics and field implementation of community engagement projects. GOPAL PRASAD UPADHYAY works on management of sustainable protected areas through people's participation. RICHARD KOCK focuses on wildlife health and emerging diseases. RAJ Amin specializes in Asian and African grassland and forest ecosystems and the development of long-term conservation projects. 